\title{
INTRACORONARY GENE TRANSFER OF IMMUNOSUPPRESSIVE CYTOKINES TO CARDIAC ALLOGRAFTS: METHOD AND EFFICACY OF ADENOVIRUS-MEDIATED TRANSDUCTION
}

Ron Brauner, MD

Lily Wu, MD, PhD

Hillel Laks, MD

Masaki Nonoyama, MD

Frank Scholl, MD

Oleg Shvarts, MS

Arnold Berk, MD

Davis C. Drinkwater, Jr., MD

Jing-Liang Wang, PhD
Objective: Allograft-targeted immunosuppressive gene therapy may inhibit recipient immune activation and provide an alternative to systemic immunosuppression. We studied the optimal technique and efficacy of intracoronary gene transfer of viral interleukin-10 and human transforming growth factor- $\beta_{1}$ in a rabbit model of heterotopic heart transplantation. Methods: Replication-defective adenoviral vectors were constructed, expressing viral interleukin-10 (AdSvIL10) or transforming growth factor- $\boldsymbol{\beta}_{1}$ (AdCMVTGF- $\boldsymbol{\beta}_{1}$ ). Intracoronary delivery of vectors was accomplished ex vivo by either bolus injection or slow infusion. The allografts were implanted heterotopically in recipient rabbits and collected 4 days after the operation. Vector dose was $4 \times 10^{9}$ to $6 \times 10^{10} \mathrm{pfu} / \mathrm{gm}$ of donor heart. Transfer was confirmed by DNA amplification for both genes. Gene product expression in tissue was quantified by immunoassay and visualized by immunohistochemical staining. Results: Allograft viral uptake was only $9.9 \% \pm 2.4 \%$ with bolus injection, but increased to $80.5 \% \pm 6.8 \%$ at 1 $\mathrm{ml} / \mathrm{min}$ infusion rate $\left(p=5 \times 10^{-14}\right)$. Uptake ratio was not affected by vector quantity or slower infusion rates. Transforming growth factor- $\beta_{1}$ was consistently detected in allografts infected with AdCMVTGF- $\beta_{1}$, but not with control adenovirus or AdSvIL10. Expression was proportional to infused vector quantity and reached $10 \mathrm{ng} / \mathrm{gm}$ of allograft at infused $10^{10}$ $\mathrm{pfu} / \mathrm{gm}$. Transforming growth factor- $\boldsymbol{\beta}_{1}$ was also detected in recipient's serum at less than $1 \mathrm{ng} / \mathrm{ml}$. Viral interleukin-10 was detected in minor amounts only ( $<1 \mathrm{ng} / \mathrm{gm}$ ) in allografts infected with AdvIL10 up to $5 \times 10^{10}$ $\mathrm{pfu} / \mathrm{gm}$. Nevertheless, it was detected in recipient serum at concentrations up to $0.4 \mathrm{ng} / \mathrm{ml}$. Conclusions: Intracoronary gene transfer of immunosuppressive cytokines to cardiac allografts during cold preservation is feasible. Slow infusion is superior to bolus injection. In vivo effects on allograft rejection remain to be determined. (J Thorac Cardiovasc Surg 1997;113: 1059-67)
The he ability of myocardial cells to uptake and express foreign recombinant DNA constitutes the basis for allograft-targeted gene therapy. A potential application is local modulation of the host

From the Division of Cardiothoracic Surgery, University of California at Los Angeles School of Medicine, Los Angeles, Calif.

Read at the Twenty-second Annual Meeting of The Western Thoracic Surgical Association, Maui, Hawaii, June 26-29, 1996.

Received for publication July 3, 1996; revisions requested Sept. 19, 1996; revisions received Oct. 21, 1996; accepted for publication Dec. 13, 1996.

Address for reprints: Hillel Laks, MD, Division of Cardiothoracic Surgery, UCLA Medical Center, 62-182A Center for the Health Sciences, 10833 Le Conte Ave., Los Angeles, CA 90095.

Copyright (C) 1997 by Mosby-Year Book, Inc.

$0022-5223 / 97 \$ 5.00+0 \quad 12 / 6 / 79880$ immune response by the genetically modified allograft, hence offering an alternative to nonspecific systemic immunosuppression. Theoretically, soluble proteins secreted within the transplanted organ should be able to exert a local in vivo effect, without requiring expression in all target cells. This strategy, however, depends on efficient gene transfer into donor hearts. Although successful transfer of reporter genes into intact hearts has been accomplished by direct myocardial injection, this method may result in uneven distribution, and inflammation at the sites of injection was reported. ${ }^{1,2}$ Recently, the feasibility of intracoronary delivery of reporter genes to allografts during cold preservation has been demonstrated, utilizing cationic liposomes ${ }^{3,4}$ and adenoviral vectors. ${ }^{5}$ 
Adenoviral vectors are the most effective vehicle for gene transfer, having a high affinity for the myocardium ${ }^{6}$ and the ability to infect nonreplicating cells at low temperature. ${ }^{7}$ For this study we used a first-generation mutant of the widespread type 5 adenovirus, which has been rendered replicationdeficient by deletions of early viral protein-encoding sequences. $^{8}$

Two multifunctional cytokines hold promise as candidates for immunosuppressive gene therapy in vivo, both having potent inhibitory functions in critical pathways of alloreactivity. Interleukin-10 (IL-10), an $18 \mathrm{kd}$ polypeptide, is a down-regulator of cytokine synthesis by Thl cells activated by monocyte-macrophage antigen-presenting cells. It inhibits monocyte-macrophage-dependent T-cell activation and antigen-presenting cell function, ${ }^{9,10}$ and has been shown to suppress alloreactivity in vivo. ${ }^{11} \mathrm{~A}$ viral homologue of IL-10 was used in this study. This protein is a product of the Epstein-Barr virus BCRF1 gene ${ }^{12}$ and shares most of the biologic and immunologic properties of the cellular cytokine. ${ }^{13}$ Transforming growth factor $-\beta_{1}\left(\right.$ TGF- $\left.\beta_{1}\right)$ is a ubiquitous $25 \mathrm{kd}$ homodimer with extensive regulatory functions. ${ }^{14}$ It has multiple effects on the immune system that include inhibition of natural killer activity, T- and B-cell proliferation and cytokine production. ${ }^{15}$ Systemically administered TGF- $\beta_{1}$ has been shown to prolong survival of heterotopic rat cardiac allografts. $^{16}$

This study evaluated the feasibility of intracoronary transfer of these functional cytokine genes into cardiac allografts at the time of cold preservation. We examined the optimal method of vector delivery and the magnitude and distribution of resulting transgene expression.

\section{Materials and methods}

Viral vectors. Adenovirus type 5 mutants were constructed by the authors (L.W., A.B.). Deletions of the entire E1a and most of the E1b regions (early viral proteins) render the vector (Ad5d1434) infectious but replication-defective. The deleted sequences were replaced by corresponding cDNA expression cassettes: For viral IL-10 (AdSvIL10), the SV40 promoter/enhancer drives the Epstein-Barr BCRF1 gene and a polyadenylation signal. In TGF- $\beta_{1}$ - encoding vectors (AdCMVTGF$\left.\beta_{1}\right)$, the human active TGF $-\beta_{1}$ cDNA is under the control of the cytomegalovirus intermediate early promoter. Viral stocks were grown in embryonic kidney (293) cells that constitutively express E1 proteins and stored at $-70^{\circ} \mathrm{C}$. Viral titers were determined by plaque assays on monolayer 293 cells and expressed as plaque-forming units per milliliter (pfu/ml). To confirm the ability of the vectors to express the encoded transgenes, 293 cells were infected and culture supernatant was assayed 24 hours after infection for both encoded proteins.

Rabbits. New Zealand White donor rabbits weighing 1.7 to $2 \mathrm{~kg}$ (Charles River Laboratories, St. Constant, Quebec, Canada) and recipients weighing 5 to $5.5 \mathrm{~kg}$ (Irish Farms, Norco, Calif.) were purchased from geographically unrelated vendors. All animals received humane care in compliance with the "Principles of Laboratory Animal Care" formulated by the National Society for Medical Research and the "Guide for the Care and Use of Laboratory Animals" prepared by the Institute of Laboratory Animal Resources and published by the National Institutes of Health (NIH Publication No. 86-23; revised 1985).

Animal management. Anesthesia was induced intravenously with ketamine $(10 \mathrm{mg} / \mathrm{kg})$ and acepromazine (1 $\mathrm{mg} / \mathrm{kg}$ ) and maintained with inhaled $1.5 \%$ isoflurane in oxygen via mechanical ventilation. Heparin (200 U/kg) was given intravenously to both donors and recipients. Recipients received cefazolin ( $40 \mathrm{mg} / \mathrm{kg}$ ) before incision.

Donor heart harvest. After sternotomy, systemic venous return to donor hearts was occluded, the pulmonary artery was transected, and the aorta was crossclamped. University of Wisconsin solution (15 ml) was injected into the proximal aorta and topical cooling was applied. The pulmonary veins were then ligated and the heart was excised and placed in cold $\left(4^{\circ} \mathrm{C}\right)$ University of Wisconsin solution.

Intracoronary gene transfer. During preservation at $4^{\circ} \mathrm{C}$, the donor aorta was cannulated. Viral vectors resuspended in $20 \mathrm{ml}$ University of Wisconsin solution were administered by either fast injection or slow infusion at 1 and $0.5 \mathrm{ml} / \mathrm{min}$. After administration of at least $10 \mathrm{ml}$, coronary sinus effluent was collected for determination of viral titers. Total quantity of infused virus was $4 \times 10^{9}$ to $6 \times 10^{10} \mathrm{pfu} / \mathrm{gm}$ of donor heart.

Transplantation. Donor hearts were transplanted in the heterotopic cervical position. The donor aorta and pulmonary artery were anastomosed to the recipient's right carotid artery and jugular vein, respectively. The recipient distal carotid artery was ligated. Topical cooling of donor hearts was maintained throughout the procedure. Average ischemic time was 55 minutes with bolus injection and 75 minutes with intracoronary delivery at a rate of $1 \mathrm{ml} / \mathrm{min}$. Additional grafts were perfused at a rate of $0.5 \mathrm{ml} / \mathrm{min}(n=3$, ischemic time $=100$ minutes $)$ or preserved for 2 hours after bolus injection $(n=3$, ischemic time $=160$ minutes). All allografts resumed spontaneous vigorous contraction within minutes of reperfusion. All recipients survived the procedure and were allowed to recover. Allografts were inspected daily by direct palpation. Cessation of mechanical activity before day 4 (in $5 \%$ ) was considered the result of technical failure.

Specimen preparation. Normally contracting grafts, recipient native hearts, and serum samples were collected on postoperative day 4 . Transmural specimens from the left and right ventricular free walls and intraventricular septum were frozen in liquid nitrogen.

Polymerase chain reaction. Flanking primers were designed for internal regions of both transgenes: for viral 
IL-10, a 461 bp region (sense: 5'-ATGGAGCGAAGGTTAGTGGTC A-3'; antisense: $5^{\prime}$-CCTGGCTTTAATTGTCATGTATGCT-3'); for TGF- $\beta_{1}$, a 243 bp region (sense: 5'-GCCCTGGACACCAACTATTGC-3'; antisense: 5'-TTGCGGCCCACGTAGTACA-3').

DNA was extracted from frozen specimens by the proteinase $\mathrm{K}$ incubation method. In brief, samples were crushed to fine powder and suspended in digestion buffer (sodium chloride, $100 \mathrm{mmol} / \mathrm{L}$; tromethamine chloride, 10 $\mathrm{mmol} / \mathrm{L}$; ethylenediaminetetraacetic acid, $25 \mathrm{mmol} / \mathrm{L}$; sodium dodecylsulfate $0.5 \% ; \mathrm{pH} 8.0$, proteinase $\mathrm{K}, 0.1$ $\mathrm{mg} / \mathrm{ml}$ ) at $80^{\circ} \mathrm{C}$ for 1 hour. Phenol/chloroform/isoamyl alcohol (25:24:1) was added in equal volumes, and then the upper aqueous phase was separated by centrifugation. This step was repeated with and without chloroform; then 2 volumes of $100 \%$ ethanol and $10 \%$ sodium acetate $\mathrm{pH}$ 5.2) were added at $-20^{\circ} \mathrm{C}$ for 1 hour. DNA precipitate was dried and resuspended in water at room temperature. Polymerase chain reaction (PCR) was performed in a DNA thermal cycler (Perkin-Elmer, Norwalk, Conn.) and consisted of 30 cycles (denaturing: $94^{\circ} \mathrm{C}-1^{\prime}$, annealing of primers: $55^{\circ} \mathrm{C}-1^{\prime}$, and extension: $72^{\circ} \mathrm{C}-1^{\prime}$ ). PCR products were separated by electrophoresis in $1.2 \%$ agarose gel, then stained with ethidium bromide. The original expression plasmids used for vector construction (pAdSvIL10 and pAdCMVTGF) served as positive controls.

Immunoassay. Heart protein was extracted from frozen specimens by homogenization in tromethamine chloride $50 \mathrm{mmol} / \mathrm{L}$, sodium chloride $150 \mathrm{mmol} / \mathrm{L}, 5 \% \beta$-mercaptoethanol, ethylenediaminetetraacetic acid $2 \mathrm{mmol} / \mathrm{L}$, and phenylmethylsulfonyl fluoride $1 \mathrm{mmol} / \mathrm{L}$, with leupeptin $25 \mu \mathrm{g} / \mathrm{ml}$, TPCK $10 \mu \mathrm{g} / \mathrm{ml}$, TLCK $10 \mu \mathrm{g} / \mathrm{ml}$, E64 5 $\mu \mathrm{g} / \mathrm{ml}$, and antipain $5 \mu \mathrm{g} / \mathrm{ml}$, at $1: 3$ dilution. Protein extract was stored in liquid nitrogen. A double-antibody capture enzyme-linked immunosorbent assay (ELISA) was used to quantify cytokines in protein extract.

Recombinant viral IL-10. Standard 96-well flat-bottom plates were coated overnight at $4^{\circ} \mathrm{C}$ with $50 \mu \mathrm{l}$ monoclonal rat antihuman/viral IL-10 antibody (Pharmigen), then washed two times with phosphate-buffered saline/Tween solution and blocked with phosphate-buffered saline solution $10 \%$ fetal calf serum for 1 hour. After being washed two times, standard, samples, and controls were added for 2 hours at room temperature. Standard curves were generated with the use of recombinant human IL-10 (kindly provided by Dr. Kevin Moore, DNAX, Palo Alto, Calif.). After the sixth wash, $100 \mu$ l secondary biotinylated monoclonal rat antihuman/viral IL-10 antibody (Pharmigen) was added at room temperature for 45 minutes, then washed six times. Avidin peroxidase was added for 30 minutes, washed eight times, and then $0.1 \%$ hydrogen peroxide in ABTS substrate was used to visualize detection. Viral culture supernatants from AdSvIL10-infected 293 cells served as positive controls.

Recombinant TGF- $\boldsymbol{\beta}_{1}$. A human TGF- $\boldsymbol{\beta}_{1}$ ELISA detection kit (Genzyme, Cambridge, Mass.) with $50 \mathrm{pg} / \mathrm{ml}$ sensitivity was used. The kit includes $96-$ well plates precoated with monoclonal mouse antihuman TGF- $\beta_{1}$. Standard recombinant human TGF- $\beta_{1}$ samples and controls were activated in $1 \mathrm{~N}$ hydrogen chloride, added to the wells for 1 hour at $37^{\circ} \mathrm{C}$, then washed five times. Detecting anti-TGF- $\beta_{1}$ histidine-rich protein conjugate was added

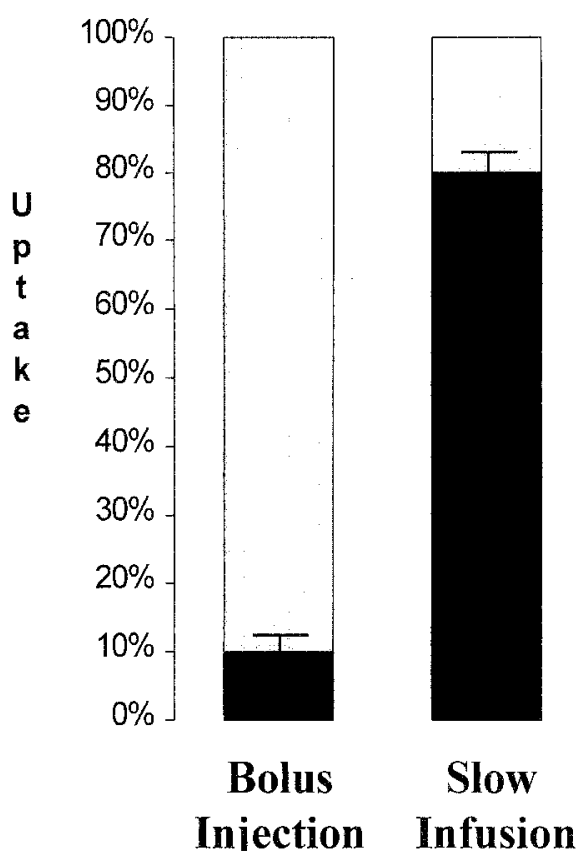

Fig. 1. Fraction viral vectors absorbed by allografts using bolus injection (left) and slow intracoronary infusion $($ right $)$. Values are expressed as mean $\pm 95 \%$ confidence intervals. The difference is highly significant $(p=5 \times$ $10^{-14}$ : Two-tailed Student's $t$ test).

for 1 hour at $37^{\circ} \mathrm{C}$, then washed five times. A color reaction was obtained by adding $2 \%$ tetramethylbenzidine and $0.03 \%$ hydrogen peroxide for 20 minutes at room temperature. Viral culture supernatants from sense and antisense AdCMVTGF- $\beta_{1}$-infected 293 cells served as positive and negative controls.

Quantification was performed on an automated ELISA plate reader (Dynatech Laboratories) at 450 $\mathrm{nm}$. Results are expressed in nanograms per gram of allograft tissue.

TGF- $\boldsymbol{\beta}_{\mathbf{1}}$ immunohistochemical staining. Frozen specimens were cryosectioned at $5 \mu \mathrm{m}$ thickness, fixed in $10 \%$ tromethamine-buffered formalin for 12 minutes at $4^{\circ} \mathrm{C}$ then rinsed with triethanolamine-buffered saline solution. Endogenous peroxidase activity was quenched by $3 \%$ hydrogen peroxide. Unspecific binding was blocked with $10 \%$ normal chicken serum and $0.2 \%$ bovine serum albumin in triethanolamine-buffered saline solution. The sections were then incubated overnight with 1:500 chicken purified (polyclonal) antihuman TGF- $\beta_{1}$ (R\&D Systems, Minneapolis, Minn.) in a humidified chamber at $4^{\circ} \mathrm{C}$. A biotinylated goat antichicken antibody and streptoavidinperoxidase complex (Vector Laboratories, Burlinghame, Calif.) were used for detection of bound primary antibodies. Immunocomplexes were visualized by aminoethylcarbazole and $0.3 \%$ hydrogen peroxide. The sections were counterstained with hematoxylin. Incubation with chicken preimmune serum at the same dilution, as well as omission of the primary antibody, did not result in positive staining, thus demonstrating specificity. 


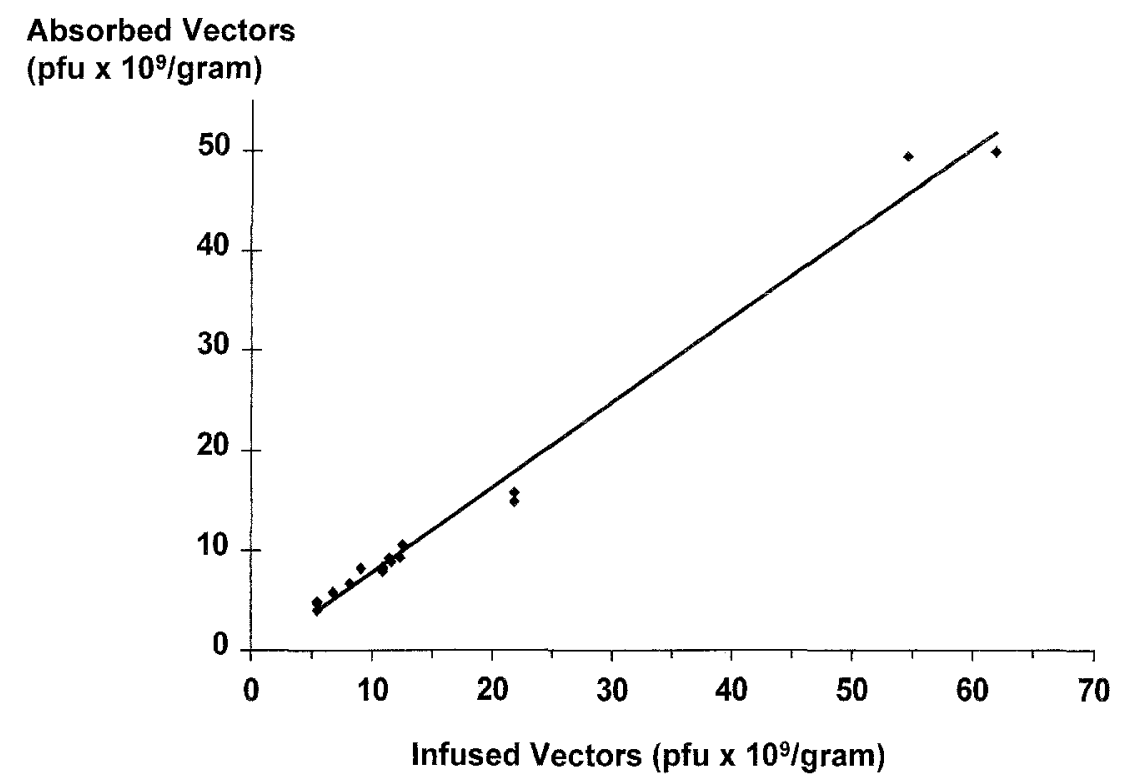

Fig. 2. At a delivery rate of $1 \mathrm{ml} / \mathrm{min}$, the correlation between infused and absorbed vector quantity is linear ( $p<10^{-4}$, Pearson's correlation). There is no decline in absorbed quantity at maximal infused quantity up to $6 \times 10^{10} \mathrm{pfu} / \mathrm{gm}$.

\section{Results}

Allograft viral uptake. Average allograft singlepass viral uptake was only $9.9 \% \pm 2.4 \%$ with bolus injection. At intracoronary infusion rates of $1 \mathrm{ml} /$ min or $0.5 \mathrm{ml} / \mathrm{min}$, maximal uptake was $91 \%$ (mean $=80.5 \% \pm 6.8 \%, p=5 \times 10^{-14}$, Student's $t$ test) (Fig. 1). Ratio uptake by allografts was constant with total infused viral quantity ranging from $4 \times$ $10^{9}$ to $6 \times 10^{10} \mathrm{pfu} / \mathrm{gm}$ of donor heart. With slow infusion, the correlation of absorbed and infused quantity of vectors was linear and highly significant throughout the range (Pearson correlation, twotailed coefficient $\mathbf{r}=0.994, p<10^{-4}$ ) (Fig. 2).

PCR. PCR was performed on grafts infected by intracoronary infusion at a rate of $1 \mathrm{ml} / \mathrm{min}$. Gene transfer was confirmed by demonstration of the presence of both inserted genes in DNA extract from corresponding allografts but not controls (Fig. 3).

TGF- $\boldsymbol{\beta}_{1}$ expression. Significant TGF- $\beta_{1}$ protein expression was detected in all allografts infected with AdCMVTGF- $\beta_{1}$ at a rate of $1 \mathrm{ml} / \mathrm{min}(n=10)$. Average level was $3.1 \pm 1.5 \mathrm{ng} / \mathrm{gr}$ (range 0.7 to 10 $\mathrm{ng} / \mathrm{gr}$ ). In contrast, only minimal TGF- $\beta_{1}$ expression was found in AdSvIL10 or control virus-infected allografts $(n=10$, mean $=0.32 \pm 0.15 \mathrm{ng} / \mathrm{gr}, p<$ $10^{-4}$, Mann-Whitney U test). Similarly, grafts infected with bolus-injected AdCMVTGF- $\beta_{1}$ at $10^{10}$ pfu/gm $(n=3)$ did not express TGF- $\beta_{1}$ above control levels. Breakdown of TGF- $\beta_{1}$ expression in the left and right ventricles and intraventricular septum is shown in Fig. 4. Although the differences in protein levels among the different regions are not significant, expression in the right ventricle was lower than in the left ventricle and septum in nine of ten tested samples $(p=0.022$, related-samples exact sign test). A correlation between TGF- $\beta_{1}$ expression and the quantity of infused vectors $(p=0.044$, Pearson correlation, twotailed) was observed (Fig. 5). TGF- $\beta_{1}$ was also detected in the serum of AdCMVTGF- $\beta_{1}$ recipients at concentrations of 0.05 to $1 \mathrm{ng} / \mathrm{ml}$, but not in controls. In the supernatant of infected 293 cells, TGF- $\beta_{1}$ levels were $>30 \mathrm{ng} / \mathrm{ml}$.

IL-10 expression. The sensitivity of viral IL-10 ELISA was $30 \mathrm{pg} / \mathrm{ml}$. Viral IL-10 was detected only in graft protein extract and recipient serum from allografts infected by slow $(1 \mathrm{ml} / \mathrm{min})$ infusion of AdSvIL10 at $10^{10}$ to $6 \times 10^{10} \mathrm{pfu} / \mathrm{gm}(n=3)$. Tissue levels ranged from 50 to $900 \mathrm{pg} / \mathrm{gm}$ (mean $=300$ $\mathrm{pg} / \mathrm{gm}$ ) and serum levels were 330 to $390 \mathrm{pg} / \mathrm{ml}$. Viral IL-10 was not detected in allografts or serum infected with AdSvIL10 at $<10^{10} \mathrm{pfu} / \mathrm{gm}(n=7)$, control virus, native hearts, or grafts infected with a bolus-injected AdSvIL10 dose of $2 \times 10^{10} \mathrm{pfu} / \mathrm{gm}$ $(n=3)$. Preservation of the grafts for 2 hours before implantation did not result in detectable viral IL-10 expression in the bolus-injected grafts $(n=3)$. 


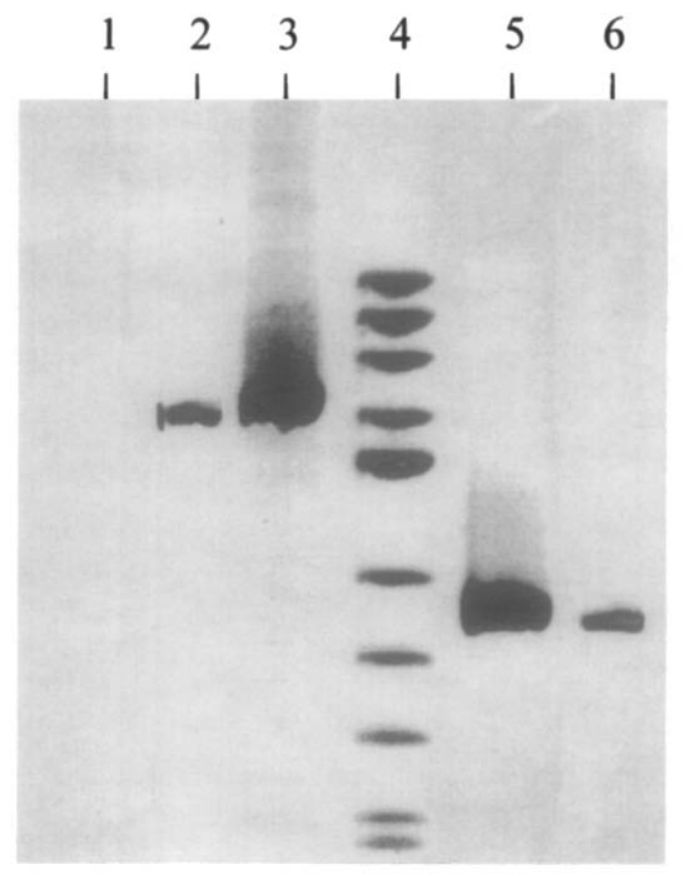

Fig. 3. PCR analysis of transgene sequences in DNA extract from representative allografts and in control plasmids: Lone 1, A graft infected with the control vector Ad5d1434 is negative for both sequences. Lane 2, A graft infected with the AdSvIL10 is positive for the expected 461 bp fragment. Lane 3, The plasmid pAdSvIL10 was the positive control for the viral IL-10 gene. Lane 4, Ladder marker. Lane 5, The plasmid pAdCMVTGF served as a positive control for detection of the expected $243 \mathrm{bp}$ human TGF- $\beta_{1}$ gene fragment. Lane 6 , A graft infected with the AdCMVTGF- $\beta_{1}$ vector.

Levels of viral IL-10 in the supernatant of infected 293 cells were up to $17 \mathrm{ng} / \mathrm{ml}$.

TGF- $\beta_{1}$ immunohistochemistry. Specific TGF- $\beta_{1}$ staining was observed in AdCMVTGF- $\beta_{1}$-infected allografts (Fig. 6). Significant TGF- $\beta_{1}$ expression was present in the extracellular matrix as well as myocytes and seemed to be more prominent in subepicardial regions.

\section{Discussion}

The current study constitutes a first attempt to construct an efficient system for intracoronary delivery of functional genes to cardiac allografts during cold preservation. The long-term goal of this experiment is to achieve expression of the inserted genes in quantities sufficient to modulate host immune responses in vivo.

Several studies suggest that efficient transduction

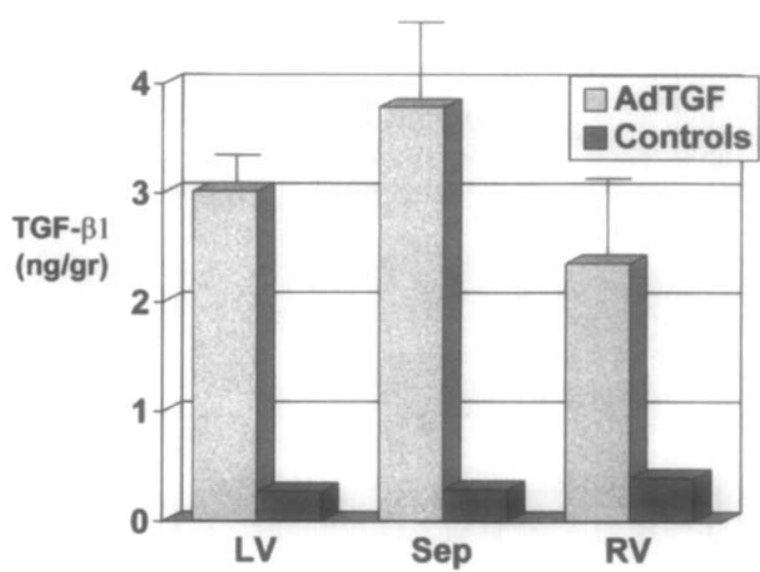

Fig. 4. Regional distribution of TGF- $\beta_{1}$ expression in left and right ventricles and intraventricular septum. The difference between AdCMVTGF- $\beta_{1}$-infected hearts and controls is statistically significant in all areas $(p<0.01$, two-tailed Student's $t$ test). Expression in the right ventricle was consistently lowest ( $p=0.022$, related-samples exact sign test). $L V$, Left ventricle; Sep, septum; $R V$, right ventricle.

of allografts may actually prolong graft survival in vivo. Systemic administration of recombinant human TGF- $\beta_{1}$ has been shown to prolong survival of cardiac allografts in the rat. ${ }^{16}$ IL-10 has also been shown to suppress alloreactivity in an in vivo mod$\mathrm{el}^{11}$ Qin and associates ${ }^{17,18}$ recently reported efficient transfer of the viral IL-10 and TGF- $\beta_{1}$ genes in nonperfused neonatal mouse cardiac allografts. Using direct myocardial injection of plasmid or retroviral expression vectors with various promoters, they achieved significant prolongation of allograft survival with both transgenes.

Replication-defective adenoviral vectors are currently the most efficient vehicle for gene transfer into nondividing cells such as myocytes. The viral particle attaches to a variety of mammalian cells through specific membrane integrin receptors, then enters the cell by endocytosis. Up to $80 \%$ of internalized viral particles reach the nucleus, where the viral genome remains episomal, thus resulting in transient expression. Exogenous DNA up to $8.3 \mathrm{~kb}$ can be used to replace the early expression regions E1, E3, and optionally E4. Viral stocks for in vivo gene transfer can be grown at very high titers. ${ }^{8}$ Although the use of viral vectors in vivo raises safety concerns, the widespread type 5 adenovirus has not been associated with any known malignant diseases and has been used for routine vaccination in human beings with no apparent side-effects. ${ }^{19}$ 


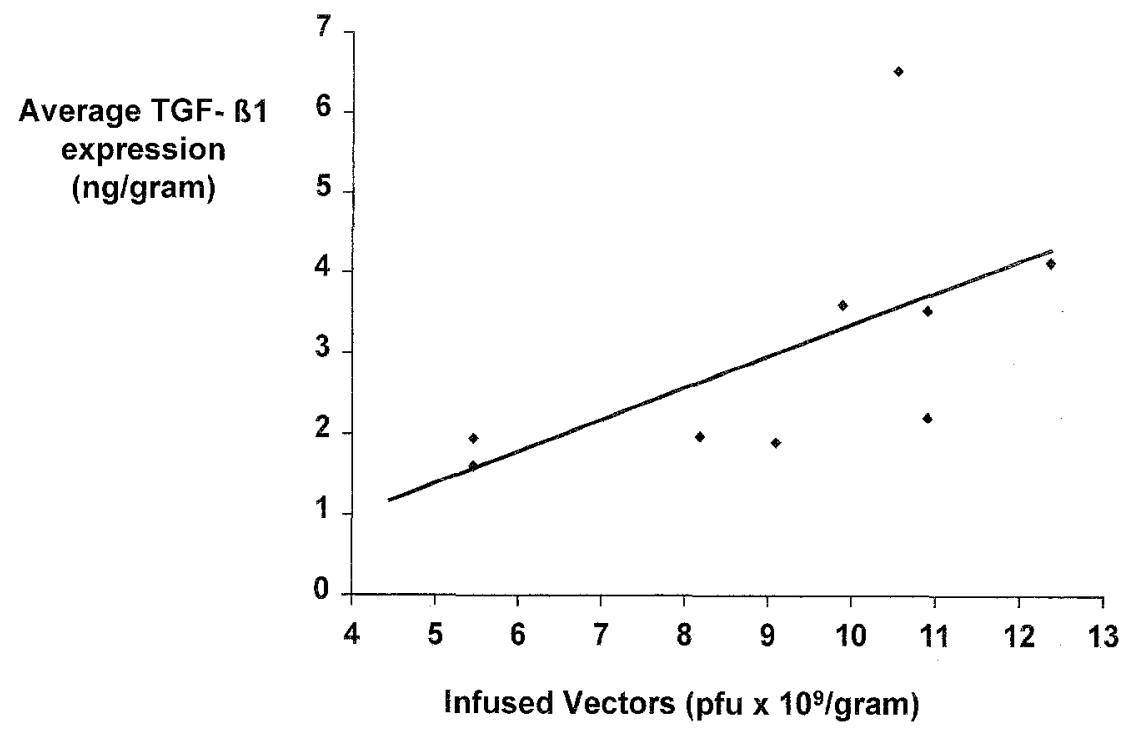

Fig. 5. TGF- $\beta 1$ expression (averaged left and right ventricles and intraventricular septum) correlates with the quantity of infused vectors ( $p=0.044$, Pearson's correlation).
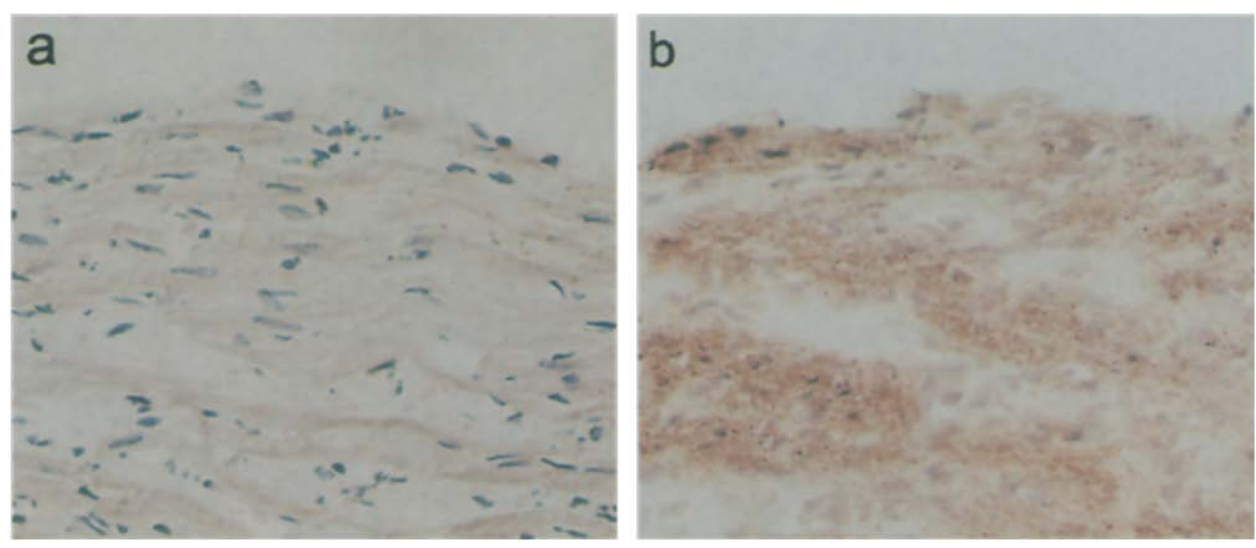

Fig. 6. Immunohistochemical staining for human $\mathrm{TGF}-\beta_{1}$ in grafts infected by slow intracoronary infusion of adenoviral vectors at $1 \mathrm{ml} / \mathrm{min}(\times 200)$. a, Subepicardial area in a graft infected with control vectors (Ad5d1434). b, Subepicardial area in a graft infected with AdCMVTGF- $\beta_{1}$. Positive immunostaining appeared as red-brown granules.

The ability of explanted hearts to uptake adenoviral vectors injected into the coronary arteries during cold preservation at $4^{\circ} \mathrm{C}$ has been qualitatively demonstrated in this laboratory. ${ }^{5}$ The distribution of reporter gene expression included myocytes as well as vascular endothelium and smooth muscle cells, but the percentage of cells expressing the transgene appeared to be small. Higher transduction rates were achieved by catheter-mediated intracoronary infusion in intact animals at normal temperature. ${ }^{20}$ The authors injected undiluted viral vectors at $1 \mathrm{ml} / \mathrm{min}$, resulting in transgene expression in up to $32 \%$ of perivascular myocytes and $100 \%$ of endothelial cells. No inflammation was noted in any of these regions.

In the present study we determined the optimal method of intracoronary vector administration by calculating the absorbed fraction of viral vectors at various rates of delivery. Although this is by no means indicative of gene product expression in tissue or even internalization of the virus into cells, it allows for a qualitative comparison of the two 
methods evaluated for vector delivery. It appears that fast injection at physiologic pressure results in inefficient $(<10 \%)$ uptake of vectors during the onepass cold coronary flush. This corresponds to in vitro data in which adenoviral vectors have been shown to require 30 minutes and 1 hour to infect $30 \%$ and $50 \%$ of cultured cells, respectively, at $4^{\circ} \mathrm{C}^{7}$ In contrast, up to $91 \%$ of diluted vectors were absorbed when infused at a rate of $1 \mathrm{ml} / \mathrm{min}$, and further reducing infusion rate to $0.5 \mathrm{ml} / \mathrm{min}$ did not result in higher uptake rates. We therefore used the slow-perfusion technique for delivery of immunosuppressive cytokine genes. This factor should be considered when attempting delivery of exogenous DNA, protein, or chemicals by intracoronary infusion.

The correlation between the quantity of infused and absorbed vectors was linear throughout the range of administered doses. This is encouraging, because a very high amount of vectors may be administered without saturating allograft receptors. We also found that the levels of transgene expression correlated with infused vector quantity, suggesting that higher expression may be achieved by incremental vector delivery. This finding is consistent with previous experience with reporter genes. ${ }^{20}$

TGF- $\beta_{1}$ expression was significant and averaged levels that have been shown to dramatically reduce lymphokine-activated killer activity and pore-forming protein mRNA expression in CD8 $+\mathrm{T}$ lymphocytes in vitro, a major pathway in alloreactivity. In addition, the induction and magnitude of T-cell cytotoxicity are significantly reduced by TGF- $\beta_{1}$ levels as low as $0.5 \mathrm{ng} / \mathrm{mll}^{15}$ The distribution of transgene expression in different regions of donor hearts was also evaluated. In a recent study of liposome-mediated intracoronary gene transfer, ${ }^{4}$ no difference was observed between reporter gene expression in the right and left ventricles. Our data show slightly lower average expression in the right ventricle when compared with the left ventricle or intraventricular septum. However, separate analysis of expression in individual allografts consistently shows lower expression in the right ventricle, this tendency being statistically significant. This can be explained by assuming that the rabbit right ventricular free wall is supplied in part by the left coronary system. If this is the case, a large amount of slowly infused vectors will be absorbed in the left ventricle and septum before reaching the right side of the heart. However, we do not have experimental support for this hypothesis.
Expression of viral IL-10 in allograft protein extract was disappointing. Viral IL-10 was specifically detected in recipient serum and allografts when viral doses higher than $10^{10} \mathrm{pfu} / \mathrm{gm}$ were used, albeit at minor levels. The possibility that vectors flushed from the graft coronary circulation at reperfusion may partly account for detectable gene expression in the recipient serum cannot be ruled out. Our failure to detect protein expression in grafts perfused with viral quantities lower than $10^{10} \mathrm{pfu} / \mathrm{gm}$ may be due to several factors: Promoter potency is known to vary among species, and a possible adverse host factor in this case cannot be ruled out. The SV40 promoter is known to be modest relative to the cytomegalovirus promoter used with the TGF- $\beta_{1}$ gene. It is even more likely that fast secretion of soluble viral IL-10 by myocytes, combined with short plasma half-life, reduces this cytokine's availability for detection. ${ }^{13}$ While TGF- $\beta_{1}$ receptors are present on all mammalian cells, the heart does not bind IL-10. This cytokine is thus largely secreted into the bloodstream, whereas a large proportion of TGF- $\beta_{1}$ is stored at the cell surface and extracellular matrix, where it can be more readily detected.

Despite these data, in vivo activity of both cytokines cannot be predicted on the basis of their levels in tissue alone. Prolongation of allograft survival may be achieved, although it is not likely to persist beyond the time course of transgene expression. Currently, the chief shortcoming of in vivo adenovirus-mediated gene transfer is its limited time course, a factor that was not addressed in this study. Although significant expression is present for up to 2 weeks in vivo, almost no residual protein is detected 1 month after delivery, and repeat administration is relatively ineffective as a result of preimmunization. ${ }^{21}$ Because this factor is determined by specific vector attributes, improved vehicles for gene therapy are constantly being developed, including second- and third-generation adenoviruses. ${ }^{22,}{ }^{23}$ Further study of the in vivo effect of this first-generation adenovirus-mediated gene transfer is warranted and may provide a glimpse into the future of allografttargeted gene therapy.

REFERENCES

1. Guzman RJ, Lemarchand P, Crystal RG, et al. Efficient gene transfer into myocardium by direct injection of adenovirus vectors. Circ Res 1993;73:1202-7.

2. Lin H, Parmacek MS, Morle G, et al. Expression of recombinant genes in myocardium in vivo after direct injection of DNA. Circulation 1990:82:2217-21.

3. Ardehali A, Fyfe A, Laks H, et al. Direct gene transfer into 
donor hearts at the time of harvest. J Thorac Cardiovase Surg 1995;109:716-20.

4. Dalesandro J, Akimoto I-L, Gorman CM, et al. Gene therapy for donor hearts: ex vivo liposome-mediated transfection. J Thorac Cardiovasc Surg 1996;111:416-22.

5. Lee J, Laks H, Drinkwater DC, et al. Cardiac gene transfer by intracoronary infusion of adenovirus vector-mediated reporter gene in the transplanted mouse heart. J Thorac Cardiovasc Surg 1996;111:246-52.

6. Stratford-Perricaudet LD, Makeh I, Perricaudet M, Briand P. Widespread long-term gene transfer to mouse skeletal muscles and heart. J Clin Invest 1992;90:626-30.

7. Csete ME, Drazan KE, van Bree $M$, et al. Adenovirusmediated gene transfer in the transplant setting. I. Conditions for expression of transferred genes in cold-preserved hepatocytes. Transplantation 1994;57:1502-7.

8. Brody SL, Crystal RG. Adenovirus-mediated in vivo gene transfer. Ann NY Acad Sci 1994;716:90-101; discussion 101-3.

9. Moore KW, A OG, de Waal Malefyt R, et al. Interleukin-10. Annu Rev Immunol 1993;11:165-90.

10. Howard M, A OG, Ishida $\mathrm{H}$, et al. Biological properties of interleukin 10. J Clin Immunol 1992;12:239-47.

11. Delvaux A, Donckier V, Bruyns C, et al. Effects of systemic administration of rIL-10 in an in vivo model of alloreactivity. Transplantation 1994;58:972-4.

12. Hsu DH, de Waal Malefyt R, Fiorentino DF, et al. Expression of interleukin-10 activity by Epstein-Barr virus protein BCRF1. Science 1990; Nov:831.

13. De Vries JE dWMK. Interleukin-10: de Vries JE, de Waal Malefyt R, editors. Austin: RG Landes, 1995.

14. Sporn MB, Roberts AB. Transforming growth factor-beta: recent progress and new challenges. J Cell Biol 1992;119: 1017-21.

15. Smyth MJ, Strobl SL, Young HA, et al. Regulation of lymphokine-activated killer activity and pore-forming protein gene expression in human peripheral blood CD8 + T lymphocytes: inhibition by transforming growth factor-beta. J Immunol 1991;146:3289-97.

16. Raju GP, Belland SE, Eisen HJ. Prolongation of cardiac allograft survival with transforming growth factor-beta 1 in rats. Transplantation 1994;58:392-6.

17. Qin L, Chavin KD, Ding $Y$, et al. Gene transfer for transplantation: prolongation of allograft survival with transforming growth factor-beta 1. Ann Surg 1994;220:508-18; discussion 518-9.

18. Qin L, Chavin KD, Ding Y, et al. Multiple vectors effectively achieve gene transfer in a routine cardiac transplantation model: immunosuppression with TGF-beta 1 or vIL-10. Transplantation 1995;59:809-16.

19. Berns KI, Giraud C. Adenovirus and adeno-associated virus as vectors for gene therapy. Ann NY Acad Sci 1995;772:95104.

20. Barr E, Carroll J, Kalynych AM, et al. Efficient cathetermediated gene transfer into the heart using replicationdefective adenovirus. Gene Ther 1994;1:51-8.

21. Ueno $\mathrm{H}, \mathrm{Li} \mathrm{JJ}$, Tomita $\mathrm{H}$, et al. Quantitative analysis of repeat adenovirus-mediated gene transfer into injured canine femoral arteries. Arterioscler Thromb Vasc Biol 1995;15: 2246-53.

22. Fisher KJ, Choi H, Burda J, et al. Recombinant adenovirus deleted of all viral genes for gene therapy of cystic fibrosis. Virology 1996;217:11-22.

23. Engelhardt JF, Ye X, Doranz B, Wilson JM. Ablation of E2A in recombinant adenoviruses improves transgene persistence and decreases inflammatory response in mouse liver. Proc Natl Acad Sci U S A 1994;91:6196-200.

\section{Discussion}

Dr. Scot H. Merrick (San Francisco, Calif.). Gene therapy is opening a new chapter and perhaps a revolution in the way we practice medicine in surgery. Transplant immunology is ideally suited for this technology, and Dr. Brauner and his colleagues are close to changing the therapeutic approach to early graft rejection. They are to be commended and encouraged, because this is a very complicated field, both technically and conceptually.

I have several questions. First, I am concerned that your method of measuring transduction efficiency or the ability of the virus to insert its DNA into the target cell is only qualitative and not quantitative. Measuring the difference between the quantity of virus introduced into the coronary circulation and the amount recovered in the coronary sinus may not be accurate inasmuch as many viruses transiently adhere to the cell surface without actually entering the cell. Have you done any staining experiments to quantify the number of cells actually transduced by your virus vector?

Dr. Brauner. The current experience with intracoronary gene transfer consists of four articles, all describing the use of reporter genes (such as $\beta$-galactosidase). The object of this work was not to use reporter genes, but obviously we cannot avoid that when performing a gene transfer experiment. We did that using the slow infusion method, and we counted the number of cells expressing $\beta$-galactosidase. A problem with this delivery method is that expression is not evenly distributed within the myocardium. What probably happens is that the virus adheres to the first cell it encounters, and this is usually in the peripheral perivascular regions. Indeed, around these regions the efficacy was $100 \%$ - every cell was infected, including endothelial, smooth muscle, and myocardial cells. As we progress toward the subendocardial regions, expression decreases to between $5 \%$ and $30 \%$, depending on the viral dose used. This is a considerable amount, nevertheless. It is the best result so far from an intracoronary transduction study. One study (by Barr and associates ${ }^{20}$ ) using in vivo intracoronary delivery achieved a $32 \%$ transduction in the perivascular regions. I do not agree that what we did is not quantitative. I believe that direct measurements of protein levels in tissue are objective and can be compared with in vitro functional data, as opposed to reporter gene expression, which can only be compared with other results using the same gene. It is therefore a good way to study the magnitude of expression but not to localize it. We did not address the distribution of transduction in this paper, only the general magnitude.

Dr. Merrick. My next question concerns gene expression. TGF- $\beta$ and $I L-10$ were under the control of two different promoters, which may explain the observed differences in expression of these two genes. More impor- 
tant, IL-10 had a very low transduction efficiency, a low tissue level, and a very high serum level. How can this be?

Dr. Brauner. I now believe that the promoters are not the main reason for the difference in gene expression. Rather, the reason is that all cells in the heart (and practically every cell in the body) have receptors for TGF- $\beta$, but there are no IL-10 receptors in the heart. IL-10 receptors are found in lymphoid tissue, such as Th1 helper cells and monocyte-macrophages. What happens is that when a TGF- $\beta_{1}$ molecule is produced it adheres to cell membranes and is not rapidly secreted, allowing for easy detection. Produced IL-10 probably gets secreted promptly, and then it is gone. Also, the plasma half-life of IL-10 is short, less than 2 hours in human beings. I now believe this is the reason for the low IL-10 detection in tissue, not that it is not produced. I believe that with any adenovirus, using similar quantities of vector should result in similar quantities of transgene expression. Indeed, the Sv40 promoter is less potent than the cytomegalovirus promoter, and the promoter is crucial for expression in tissue, but Sv40 is not a weak promoter; rather, it is a moderately potent promoter.

Dr. Merrick. You have also found higher transfection in the left ventricle than in the right ventricle. Do you have any theories to explain this?

Dr. Brauner. A relationship may exist between the magnitude of expression and the absolute quantity of perfusate to the respective tissue. However, the literature suggests that the right ventricle gets transduced less even with local injection, which is hard to explain. I really do not know why that is happening.

Dr. Merrick. Finally, TGF- $\beta_{1}$ has known neoplastic and fibroblastic effects. Do you have any concerns that this cytokine may actually increase the risk of graft arteriosclerosis?

Dr. Brauner. That question has been addressed specifically in a study (by Qin and associates ${ }^{18}$ ) in which nonperfused neonatal mouse hearts were implanted in the ear pinnae of genetically identical mice and survived for long periods. The hearts were injected with TGF- $\beta_{1}-$ encoding plasmid. The authors looked specifically for growth factor effects of TGF- $\beta_{1}$, such as intimal prolifer- ation and fibrosis, and they did not find any. We know of no other reports of cardiac gene transfer with TGF- $\beta_{1}$. We did not have a long enough survival time to look at that, but it is still a relevant concern.

Dr. Robert C. Robbins (Stanford, Calif.). I think it is a good idea to look at either fuorescein labeling or isotope labeling to try to find your gene. At last year's meeting a paper about methodology was presented by a group from Seattle. What about results? Have you evaluated allograft survival using these methods?

Dr. Brauner. I expected this question to come up. If the question is, does the technique prolong allograft survival, the answer is yes, both genes do. However, this is preliminary information, and we will have to wait for final results.

Dr. Robbins. How much does it prolong survival? We are doing similar experiments at Stanford looking at gene therapy at different targets, such as intracellular adhesion molecule (ICAM), and we are seeing prolongation in a rat model. I would be interested to hear the length of allograft survival in a rabbit model.

Dr. Brauner. The problem with this first-generation virus is the limited time course of expression. The probable reason is that some viral proteins are produced by this virus and expressed at the cell surface, eliciting an immune response. It is unlikely that prolongation of graft survival would extend beyond the time course of infection of the virus. Basically, if rejection occurs after more than 10 days in untreated animals, it may not be a good model for such a study. If rejection in controls occurs in 6 to 7 days, as is the case in this rabbit model, then one may observe a consistent and significant prolongation of survival to the time of expression of the virus, which is about 11 days or even longer.

Dr. Robbins. I think this points out one of the limitations of this methodology.

Dr. Brauner. Yes, but one should not give up, because better vectors are being constructed all the time. Actually, only 3 months ago a vector that is deleted of all viral proteins was reported (by Fisher and associates ${ }^{22}$ ) at the Institute of Human Gene Therapy in Philadelphia. This is very promising, because it will probably extend expression, while other research is going on as well. 